\title{
Understanding soil health and associated farmers' perceptions in Colombian coffee systems
}

\author{
F. Rekik, H. van Es, J.N. Hernandez-Aguilera, and M.I. Gómez
}

\begin{abstract}
Soil health (SH) is important to the economics and environmental impacts of crop production, including coffee (Coffea spp.) culture. This study was conducted to gain insights into farmers' perceptions related to $\mathrm{SH}$ concepts and their realities on Colombian coffee farms. A total of 223 soil samples were collected from 145 coffee farms in Cauca, Colombia, that vary by municipality, their membership status with a coffee co-op (member or nonmember), and farmer gender. Samples were analyzed for $13 \mathrm{SH}$ indicators, including wet aggregate stability (WAS), available water capacity (AWC), respiration rate, $\mathrm{pH}$, active carbon $(A C)$, organic matter $(\mathrm{OM})$, protein, phosphorus $(\mathrm{P})$, potassium $(\mathrm{K})$, magnesium $(\mathrm{Mg})$, iron $(\mathrm{Fe})$, manganese $(\mathrm{Mn})$, and zinc $(\mathrm{Zn})$. Farmer co-op membership and municipality, but not farmer gender, were significant factors for SH status on farms. Farmer co-op members were asked to identify on their farms the plot that they perceived to have the highest soil fertility and the plot with the lowest soil fertility, which allowed for the evaluation of (1) the correctness of farmers' SH perception, i.e., whether their perception was aligned with or similar to scientific measurements of SH, and (2) which SH indicators strongly influence farmer perception of SH. Farmers' perceptions were found to be in line with the scientific laboratory measurements of $\mathrm{SH}$, and their perceptions were significantly positively influenced by the soil's organic matter and protein contents but negatively influenced by soil respiration. Finally, $\mathrm{SH}$ perception correctness was not correlated with farmer gender, locality, or SH conditions.
\end{abstract}

Key words: Cauca—farmer co-op membership—farmer gender-level of alignmentperception study

\begin{abstract}
Soil health (SH) can be a prime determinant of agricultural productivity in terms of both quality and quantity of yields. The ability to manage for $\mathrm{SH}$ is crucial for environmental and economic reasons, especially for high value, globally traded commodity crops like coffee (Coffea spp.), for which actual or perceived sustainability may offer a marketing advantage (e.g., Rainforest Alliance, Fair Trade, Smithsonian Bird Friendly). In the current context of low profitability and climate variability, which negatively affect coffee growers and industry sustainability (HernandezAguilera et al. 2019), there is an interest in approaches that combine product quality improvements with farmer enrollment in
\end{abstract}

Received December 21, 2018; Revised November 5, 2019; Accepted November 18, 2019.
Farmers generally want to know the health of their soils. In-field assessments are often the only option for subsistence farmers due to the high cost of laboratory analyses, and farmers can save time, money, and energy if they are able to qualitatively assess their $\mathrm{SH}$ and manage it accordingly. Previous perception studies in natural settings have predominantly revolved around environmental conscience and farmer climate-change awareness. One study (Rahman 2005) assessed farmer awareness of adverse environmental impacts caused by agricultural technology, and another study (Munyuli 2011) addressed the key concepts in farmer perception and management of natural resources (among others), but they were not explicitly linked to $\mathrm{SH}$ or soil fertility. Recent literature found evidence that farmer perception of historical climate events is reflected in multiple remote sensing climate records, suggesting that there is legitimacy in farmers' reporting of data on seasonal vulnerabilities (Osgood et al. 2018). Very few studies have assessed farmer $\mathrm{SH}$ perception. Munyuli (2011) conducted a gender-based farmer study on their perceptions of the importance of pollinators in coffee production in Uganda, which briefly touched upon the issue of $\mathrm{SH}$. It revealed that female farmers are more aware of the concept of soil fertility restoration as a basic component of coffee production enhancement than male farmers. Additional studies in other cropping systems found that farmers typically associate $\mathrm{SH}$ with organic matter (OM) content, followed by crop appearance and biological activity (Romig et al. 1995; de Bruyn and Abbey 2003; Karltun et al. 2013). In addition, findings by Ryder (2003) suggest that farmer perceptions of soil fertility may vary regionally. Notwithstanding, understanding farmers' holistic perception of SH will enable researchers, educators, and extension workers to better communicate

Fatma Rekik is a graduate student and Harold van Es is a professor of soil and water management at the Soil and Crop Sciences Section, School of Integrative Plant Science, Cornell University, Ithaca, New York. J. Nicolas Hernandez-Aguilera is a postdoctoral research fellow at the International Research Institute for Climate and Society and the Earth Institute, Columbia University, New York, New York. Miguel I. Gómez is an associate professor at the Charles H. Dyson School of Applied Economics and Management, Cornell University, Ithaca, New York. 
with farmers about $\mathrm{SH}$ and help them fill knowledge gaps (Karltun et al. 2013).

The objectives of this study are to (1) identify whether farmer gender, co-op association, and locality are associated with overall SH in Colombian coffee farms; (2) identify the quantitative $\mathrm{SH}$ indicators that influence how farmers perceive their $\mathrm{SH}$; (3) assess whether Colombian coffee farmers have correct perceptions of their $\mathrm{SH}$; and (4) identify factors that influence farmers' correct perceptions of $\mathrm{SH}$.

\section{Materials and Methods}

Project Location and Site Description. This study was performed in a predominantly coffee-growing region within the Department of Cauca (equivalent to state), Colombia (approximately $2.2^{\circ} \mathrm{N}, 76.4^{\circ} \mathrm{W}$; figure 1). Farms selected in this study were situated at elevations ranging between 1,269 and $1,959 \mathrm{~m}$, which provide favorable conditions for coffee cultivation in the tropics. Average rainfall in Cauca ranges between 261 and $313 \mathrm{~mm} \mathrm{y}^{-1}$ and has a bimodal distribution centered around the months of April and November (computed from Promedios Climatológicos 1981 - 2010.xlsx [IDEAM n.d.]). The soils are Andisols of volcanic ash origin, according to Saul Antonio Agredo (personal communication, March
12, 2015). Coffee production in the region is mainly conducted by small-scale farmers as either monoculture or polyculture, with an average farm size less than 5 ha. Crops that accompany coffee trees in polyculture settings typically include a variety of shade tree species to provide canopy cover for the coffee and other ecosystem services. These trees were mainly guamo (or pacay, Inga edilus), avocado (Persea americana), nogal (or walnut, Juglans spp.), and orange (Citrus reticulata).

Coffee growers in our study area were selected from two coffee marketing groups: 78 farmers who were members of a co-op that operates under an alternative business model called Relationship Coffee Model (RCM) that promotes transparency, traceability, and active engagement of smallholders throughout the value chain, and 67 farmers who were not members of the said co-op (table 1). The RCM places high coffee quality ("specialty coffee") at the core of the commercial relationship for which member farmers are expected to undertake more sustainable farming practices, such as shadegrown coffee. Thus, these member farmers have better access to price premiums, certification, and credit, while nonmember farmers sell to the regular commodity market, which yields less collective goods.

\section{Figure 1}

Project location in the Department of Cauca, Colombia, including the six surveyed municipalities. Reprinted from Rekik et al. (2018).

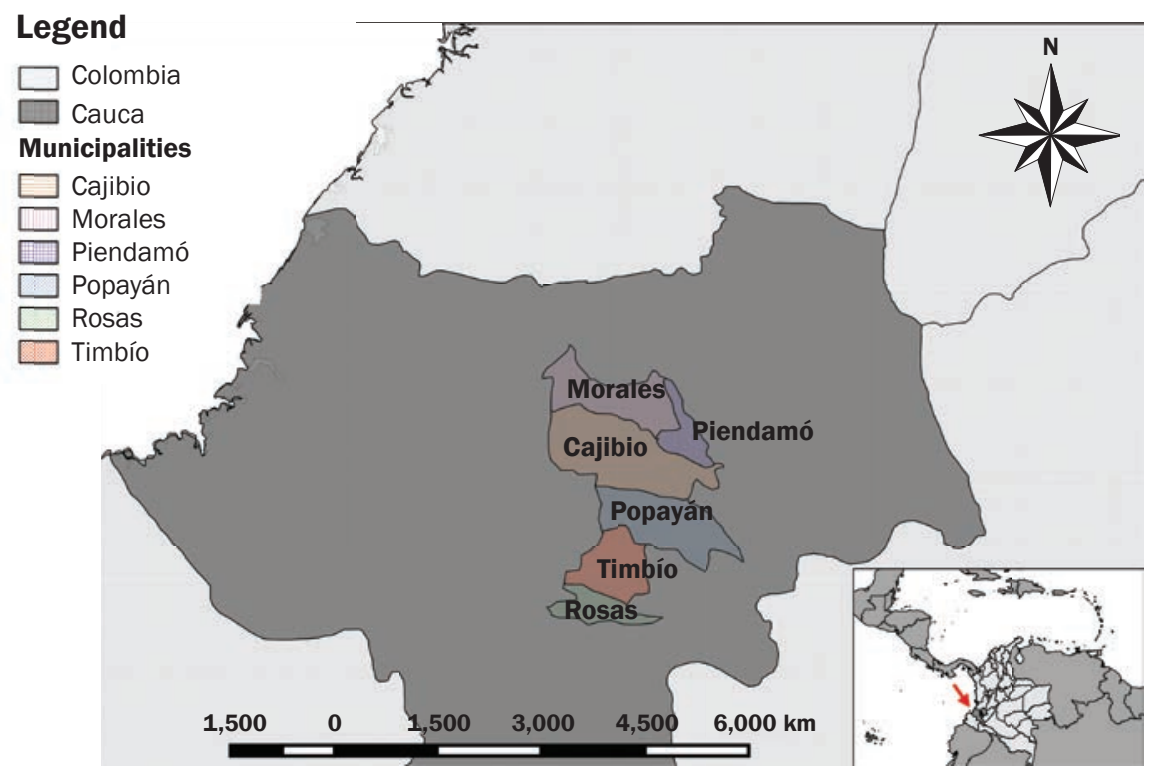

Sampling, Analysis, and Scoring Methods. A total of 223 soil samples were collected in January of 2014 from 145 coffee farms across six municipalities in Cauca, Colombia (Cajibio, Timbío, Rosas, Piendamó, Morales, and Popayán). At each sampling location, five soil cores ( 0 to $15 \mathrm{~cm}$ deep) at a distance of at least $4.5 \mathrm{~m}$ apart were collected using a Dutch-style soil auger and combined into one composite sample. In such way, 1 composite soil sample was collected from each nonmember farm, yielding 67 soil samples, and 2 composite soil samples were collected from member farms-one from the area that is perceived by the farmer to be "the most fertile" and another from the area that is perceived by the farmers to be "least fertile" without further guidance. Basic demographic information about the coffee growers was collected, including gender, membership status with RCM co-op, and location. Soil samples were sent to Cornell University in Ithaca, New York, and analyzed following the protocol devised by the Comprehensive Assessment of Soil Health (CASH) framework (Moebius-Clune et al. 2016), which included the assessment of physical (wet aggregate stability [WAS] and available water capacity [AWC]), biological (OM, active carbon $[\mathrm{AC}]$, protein, and respiration), and chemical ( $\mathrm{pH}$, phosphorus $[\mathrm{P}]$, potassium $[\mathrm{K}]$, magnesium $[\mathrm{Mg}]$, iron $[\mathrm{Fe}]$, manganese $[\mathrm{Mn}]$, and zinc [Zn]) indicators (Moebius-Clune et al. 2016). Scoring followed the method of Rekik et al. (2018), modified after Moebius-Clune et al. (2016) and Andrews et al. (2004), which consisted of comparing each individual measurement to a standardized dataset of soil samples specific to the region using a cumulative normal distribution (CND) function where the parameters $\mu$ and $\sigma$ were either estimated by the sample mean $(m)$ and standard deviation $(s)$, respectively (for the case of physical and biological indicators), or were based on outcome-based thresholds (for the case of chemical indicators), while adjusting for texture grouping (fine, medium, or coarse).

Statistical Methods. Analysis of variance (ANOVA) was performed on the entire dataset $(n=223)$ to assess which factors, including gender, co-op membership, and locality, are associated with farm overall $\mathrm{SH}$. ANOVA assumptions were checked and mean separation was computed using Tukey's test at $\alpha=0.05$. 
Logistic regression and principal component analysis (PCA) were additionally performed to evaluate which $\mathrm{SH}$ indicators most affect farmer SH perception. The logistic regression was based on standardized $\mathrm{SH}$ indicator measurements $\left[\gamma^{\prime}=(\gamma-m) \div s\right]$ to adjust for variation arising from the different indicator units.

Finally, the relationship of farmer gender, locality, and actual farm SH conditions with farmer perception correctness was analyzed by tallying the number of individuals who correctly and incorrectly ranked their soils in each gender, municipality, and $\mathrm{SH}$ group and conducting Fisher's Exact Test for Count Data - a more accurate test than chi-square test when the expected numbers are less than 1,000 (McDonald 2014). CASH classification of the overall $\mathrm{SH}$ score was used in the assessment of the effect of actual SH conditions on perception correctness and categorized using the following scale: very high, high, medium, low, and very low, with lower range limits at $85,70,55,40$, and 0 , respectively (MoebiusClune et al. 2016). All statistical analyses were performed using the R-Project for Statistical Computing (R Core Team 2014).

\section{Results and Discussion}

Soil Health Descriptive Statistics. Table 2 shows measured $\mathrm{SH}$ indicator values and the overall $\mathrm{SH}$ index score (scale from 0 to 100) for each municipality. WAS, AWC, OM, $\mathrm{AC}$, respiration, $\mathrm{P}, \mathrm{Mg}$, and $\mathrm{Mn}$ differed significantly across municipalities, where Rosas consistently has the lowest measured values for all physical and biological indicators and among the highest in chemical indicators, except for P. Conversely, Morales has among the highest measured $\mathrm{SH}$ values among the municipalities. Consequently, Rosas scored the lowest overall SH $(53.0 \pm 9.0)$, while Morales scored the highest overall $\mathrm{SH}(70.3$ \pm 7.4 ), which highlights the importance of physical and biological indicators in the assessment of SH (Moebius-Clune et al. 2016). The average overall $\mathrm{SH}$ index score for the entire studied region is 59.7 (table 2). Notably, aggregate stability values were universally high $(94.3 \%)$, presumably due to the volcanic origin of the soils combined with undisturbed soil in a perennial cropping system.

Results from the PCA reveal that the first principal component (PC), explaining $34 \%$ of total variability, is strongly associated with seven $\mathrm{SH}$ indicator variables, including all physical and biological indicators, plus $\mathrm{P}$ (table 3; figure 2). Specifically, PC 1 increases with increasing $\mathrm{OM}, \mathrm{AC}, \mathrm{AWC}$, respiration, $\mathrm{P}$, WAS, and protein, in descending order, suggesting that these seven indicators vary together. Since PC 1 correlates most strongly with OM $(r=0.930)$, we conclude that this $\mathrm{PC}$ is primarily an indicator of broader benefits associated with higher OM levels in soil (table 3). The second PC explains 17\% of total variability and is related to increasing levels of $\mathrm{K}, \mathrm{Zn}, \mathrm{Mn}$, and protein, in descending order. This component can be viewed as a measure of the chemical indicators of $\mathrm{SH}$, suggesting that nutrient availability tends to be consistent across individual nutrients that are generally co-managed (figure 2; table 3 ).

Factors Affecting Soil Health. Results from the ANOVA showed that overall $\mathrm{SH}$ index scores differ significantly between farmer co-op membership status ( $p=0.04$; table 4 and figure 3 ) and among municipalities $(p<0.001$; table 4 and figure 3$)$, but not between farmer gender (table 5). Members of the farmer co-op have significantly higher mean overall $\mathrm{SH}$ index scores than their counterparts, indicating that on average the RCM-provided agricultural services are associated with a measurable increase in $\mathrm{SH}$. The Morales municipality showed the highest mean $\mathrm{SH}$ index score, while Rosas

\section{Table 1}

Demographic information of surveyed coffee growers: 78 member farmers composed of 50 male, 25 female, and 3 not surveyed farmers, and 67 nonmember farmers composed of 51 male and 16 female farmers.

\begin{tabular}{lrrl}
\hline Municipality & Male & Female & NA* \\
\hline Co-op members & 9 & 4 & \\
Rosas & 9 & 4 & 3 \\
Timbío & 7 & 3 & \\
Piendamó & 7 & 6 & 3 \\
Cajibio & 9 & 4 & \\
Morales & 9 & 4 & \\
Popayán & 50 & 25 & \\
Total $(n=78)$ & & 3 & \\
\hline Co-op nonmembers & 9 & 3 & \\
Rosas & 9 & 4 & \\
Timbío & 8 & 1 & \\
Piendamó & 10 & 4 & \\
Cajibio & 6 & 1 & \\
Morales & 9 & 16 & \\
Popayán & 51 & & \\
Total $(n=67)$ & 101 & &
\end{tabular}

has the lowest (figure 3). This is likely due to inherent soil properties rather than large changes in soil management; nevertheless, this has both direct and indirect implications in the coffee production setting. These relationships are correlations that can hopefully motivate future research in causality while controlling for these factors.

Soil Health Indicators Influencing Farmer Soil Health Perceptions. Given the high variability in the first PC (34\%) compared to the other PCs (17\% and 10\%), as shown in the PCA (table 3), we parsimoniously selected the seven indicators highlighted by the first PC (WAS, AWC, OM, AC, protein, respiration, and $\mathrm{P}$ ) to include in a logistic regression analysis. From these, farmer perception of SH shows a significantly positive correlation with protein $(p<0.001$; table 6$)$ and OM $(p<$ $0.001)$, validating that farmers often perceive high OM as a sign of good SH (Knutson et al. 2011) and that OM is a commonly used indicator of soil fertility (Karltun et al. 2013). Conversely, farmer perception of $\mathrm{SH}$ shows significant negative correlation with respiration $(p=0.02)$. It is unclear why this is the case; although, it may have to do with collinearity. In general, however, farmers in our and previously mentioned studies seem to have a good understanding that higher OM 
Table 2

Summary of soil health results (mean [sd]) for the Department of Cauca $(n=223)$ and its municipalities, including measured values and overall soil health index score.

\begin{tabular}{|c|c|c|c|c|c|c|c|}
\hline Indicator & Rosas & Timbío & Popayán & Cajibio & Piendamó & Morales & Cauca \\
\hline WAS (\%) & $90.2(14.1) b$ * & 92.4 (6.3)ab & $96.2(5.4) a$ & 97.4 (1.7)a & 96.7 (3.1)a & $97.0(2.3) a$ & $94.3(8.3)$ \\
\hline $\operatorname{AWC}\left(\mathrm{g} \mathrm{g}^{-1}\right)$ & $0.2(0.1) d$ & $0.2(0.1) \mathrm{cd}$ & $0.3(0.1) b c$ & $0.3(0.1) b c$ & $0.4(0.1) a$ & $0.3(0.1) a b$ & $0.3(0.1)$ \\
\hline $\mathrm{OM}(\%)$ & $12.9(5.8) \mathrm{c}$ & $16.7(5.3) b$ & $17.4(4.8) b$ & 20.1 (5.9)ab & $19.4(5.5) a b$ & $22.7(3.4) a$ & $17.4(6.0)$ \\
\hline $\mathrm{AC}(\mathrm{ppm})$ & $666.4(237.0) c$ & $798.0(196.2) b$ & $830.5(212.5) b$ & 896.2 (223.0)ab & 857.3 (251.6)ab & 1,011.3 (172.2)a & $818.3(237.7)$ \\
\hline Protein $\left(\mathrm{mg} \mathrm{g}^{-1}\right)$ & $8.7(2.4) \mathrm{a}$ & 9.5 (2.1)a & $8.7(2.7) a$ & $10.1(2.7) a$ & 9.5 (3.0)a & $9.6(2.2) a$ & $9.2(2.5)$ \\
\hline $\begin{array}{l}\text { Respiration } \\
\left(\mathrm{mg} \mathrm{CO}_{2} \mathrm{~g}^{-1}\right)\end{array}$ & $0.9(0.3) c$ & $1.0(0.2) b c$ & $1.0(0.3) b c$ & $1.1(0.3) a b$ & $1.0(0.3) a b c$ & $1.2(0.2) \mathrm{a}$ & $1(0.2)$ \\
\hline $\mathrm{pH}$ & 4.9 (0.3)a & $4.8(0.3) a$ & $4.8(0.4) a$ & $4.7(0.3) \mathrm{a}$ & 4.7 (0.3)a & $4.8(0.3) \mathrm{a}$ & $4.8(0.3)$ \\
\hline $\mathrm{P}(\mathrm{ppm})$ & $7.4(3.7) d$ & $9.9(3.2) b c$ & $8.6(3.5) \mathrm{cd}$ & $8.9(3.9) \mathrm{cd}$ & 12.5 (5.8)ab & $12.9(3.7) a$ & $9.6(4.3)$ \\
\hline $\mathrm{K}(\mathrm{ppm})$ & $112.0(60.8) a$ & $130.3(91.4) a$ & $126.9(111.2) a$ & 99.5 (65.9)a & $104.0(67.2) \mathrm{a}$ & $100.4(51.2) a$ & $115.4(80.9)$ \\
\hline $\mathrm{Mg}(\mathrm{ppm})$ & 315.1 (443.1)a & 159.0 (291.0)ab & $103.9(212.5) b$ & 254.7 (665.0)ab & $60.1(52.9) \mathrm{b}$ & $51.2(30.0) \mathrm{b}$ & 169.9 (361.6) \\
\hline $\mathrm{Fe}(\mathrm{ppm})$ & $22.3(14.4) a$ & $19.0(10.7) a$ & $18.6(6.2) a$ & $20.2(16.4) a$ & $21.8(10.1) a$ & $23.0(5.3) a$ & $20.6(11.2)$ \\
\hline $\mathrm{Mn}(\mathrm{ppm})$ & $8.0(5.2) a b$ & 8.5 (4.5)a & $4.7(4.0) \mathrm{cd}$ & $6.6(5.2) \mathrm{abc}$ & $5.3(3.1) \mathrm{bcd}$ & $3.0(2.0) d$ & $6.4(4.7)$ \\
\hline Zn (ppm) & 1.0 (1.0)a & $0.8(0.6) a$ & $1.0(0.9) a$ & 0.8 (0.8)a & 0.9 (1.0)a & $1.0(0.9) a$ & $0.9(0.9)$ \\
\hline Soil health & $53.0(9.0) d$ & $57.5(7.8) \mathrm{cd}$ & $58.8(11.1) b c$ & 62.7 (9.0)abc & 64.3 (12.5)ab & $70.3(7.4) a$ & $59.7(10.8)$ \\
\hline
\end{tabular}

index score

Notes: WAS = wet aggregate stability. AWC = available water capacity. $\mathrm{OM}=$ organic matter. $\mathrm{AC}=$ active carbon. $\mathrm{P}=$ phosphorus. $\mathrm{K}=$ potassium. Mg $=$ magnesium. $\mathrm{Fe}=$ iron. $\mathrm{Mn}=$ manganese. $\mathrm{Zn}=$ zinc.

*a, b, c, and d are significant homogeneous groups among municipalities using Tukey's HSD at $p<0.05$.

\section{Table 3}

Dimensional loadings and explanation of variance of first three principal components. Bolded values represent strong correlation $(|r|>0.50)$.

\begin{tabular}{lccc}
\hline Indicator & PC 1 & PC 2 & PC 3 \\
\hline WAS & $\mathbf{0 . 6 6 2}$ & 0.097 & 0.174 \\
AWC & $\mathbf{0 . 7 6 1}$ & -0.052 & -0.272 \\
OM & $\mathbf{0 . 9 3 0}$ & -0.026 & -0.040 \\
AC & $\mathbf{0 . 8 8 3}$ & 0.175 & -0.228 \\
Protein & $\mathbf{0 . 5 7 0}$ & $\mathbf{0 . 5 1 1}$ & 0.225 \\
Respiration & $\mathbf{0 . 7 0 7}$ & 0.487 & -0.021 \\
pH & -0.214 & 0.434 & $\mathbf{- 0 . 7 7 8}$ \\
P & $\mathbf{0 . 7 0 3}$ & -0.148 & 0.300 \\
K & -0.170 & $\mathbf{0 . 6 9 1}$ & 0.004 \\
Mg & -0.471 & 0.433 & -0.178 \\
Fe & -0.182 & 0.139 & 0.386 \\
Mn & -0.379 & $\mathbf{0 . 6 1 0}$ & 0.453 \\
Zn & -0.023 & $\mathbf{0 . 6 3 0}$ & 0.048 \\
\hline Standard deviation & 2.1118 & 1.4845 & 1.1370 \\
\hline \% of variance & 34.304 & 16.952 & 9.945 \\
\hline Cumulative \% of variance & 34.304 & 51.256 & 61.201 \\
\hline
\end{tabular}

Notes: WAS = wet aggregate stability. AWC = available water capacity. $\mathrm{OM}=$ organic matter. $\mathrm{AC}=$ active carbon. $\mathrm{P}=$ phosphorus. $\mathrm{K}=$ potassium. $\mathrm{Mg}=$ magnesium. $\mathrm{Fe}=$ iron. $\mathrm{Mn}=$ manganese $\mathrm{Zn}=$ zinc.

is associated with better coffee cultivation as it provides nutrients and water to coffee trees and promotes biological activity and nutrient cycling, and that protein-a nitrogen (N)-based compound-boosts coffee yields. It is noted that in this region, soil aggregate stability, another common visual indicator of $\mathrm{SH}$, is universally high due to the volcanic origin of the soils and the perennial cropping system (table 2), implying less opportunity for farmer differentiation of soils based on this indicator.
Farmer Perception Correctness. Coffee growers in general tend to be aware of relative $\mathrm{SH}$ on their farms, with three times as many correctly versus incorrectly ranking higher and lower fertility plots when comparing their respective $\mathrm{SH}$ index scores (76\% correct versus $24 \%$ incorrect; data not shown). In addition, the average overall SH index score is significantly higher for plots that growers identified as most fertile compared to the least fertile $(62 \%[s=11]$ and $57 \%[s=12]$, respectively; $p=0.01$; data not shown). This confirms the finding of Karltun et al. (2013) who concluded that "there is good agreement between farmers' knowledge (of SH) and scientific indicators of soil fertility."

Given that coffee farmers tended to correctly perceive relative $\mathrm{SH}$ on their farms, interest lies in knowing whether gender, affiliation to a municipality, or actual $\mathrm{SH}$ influences their perception. Fisher's Exact Test for Count Data did not determine a difference between male and female farmers ( $p=0.77$; data not shown), among farmers from different municipalities $(p=0.5$; data not shown), or among actual overall $\mathrm{SH}$ classes ( $p=0.10$; data not shown).

\section{Summary and Conclusions}

This study was conducted to evaluate the demographic factors that affect $\mathrm{SH}$ on Colombian coffee farms, which SH indicators influence farmer perception of $\mathrm{SH}$, 


\section{Figure 2}

Principal component analysis variables factor map of soil health indicator measurements. WAS = wet aggregate stability. $\mathrm{AWC}=$ available water capacity. $\mathrm{OM}=$ organic matter. $\mathrm{AC}=$ active carbon. $\mathrm{P}=$ phosphorus. $\mathrm{K}=$ potassium. $\mathrm{Mg}=$ magnesium. $\mathrm{Fe}=$ iron. $\mathrm{Mn}=$ manganese. $\mathrm{Zn}=$ zinc.

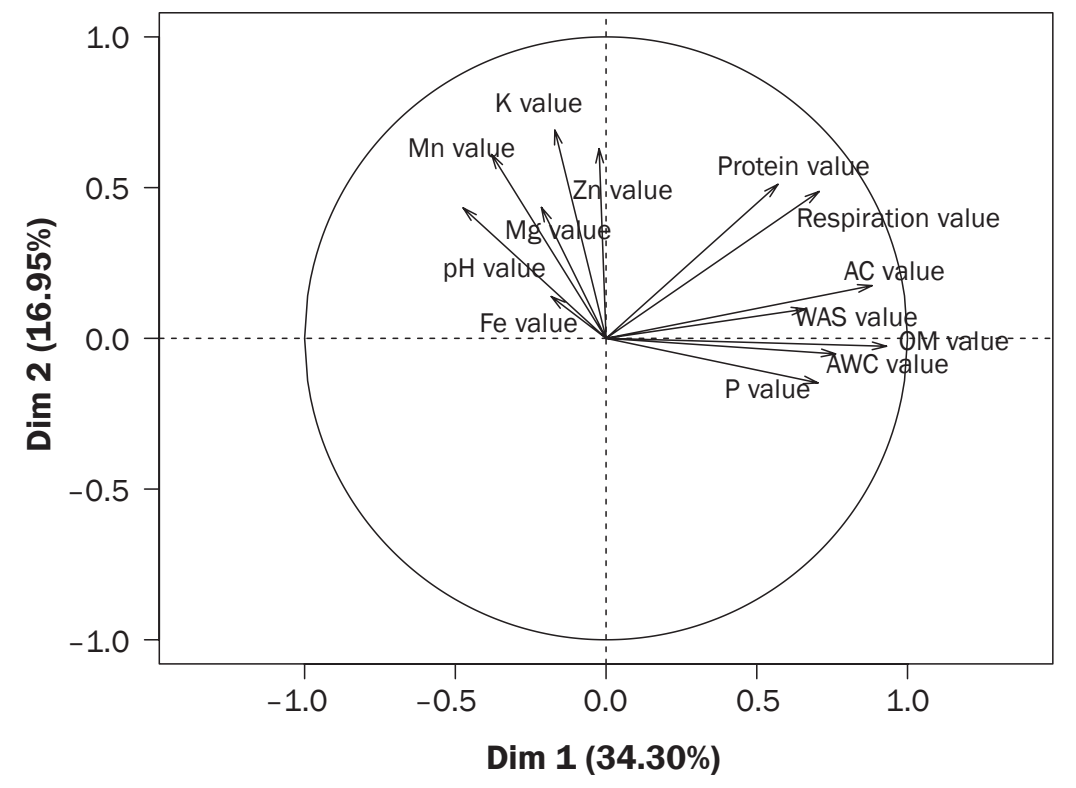

Table 4

ANOVA of demographic factors affecting overall soil health index score.

\begin{tabular}{llll}
\hline Factor & df & F value & $\operatorname{Pr}(>\boldsymbol{F})$ \\
\hline Co-op membership & 1 & 4.328 & 0.0394 \\
Gender of farmer & 1 & 0.446 & 0.5054 \\
Municipality & 5 & 7.930 & $<0.001$
\end{tabular}

whether farmers can correctly perceive $\mathrm{SH}$ on their farms, and what studied factors influence farmer perception correctness. Our findings suggest that seven variables (OM, AC, AWC, respiration, P, WAS, and protein) are strongly related to $\mathrm{SH}$ and that $\mathrm{SH}$ itself varies across the six municipalities. Co-op member farms had on average higher $\mathrm{SH}$ than nonmember farms, which suggests that the co-op services are associated with better SH. Furthermore, most coffee farmers correctly ranked soils that were "most fertile" and "least fertile" on their farms, which was not associated with locality, farmer gender, or how healthy their soil actually was. Finally, $\mathrm{OM}$, protein, and respiration are indicators that are most related to farmer $\mathrm{SH}$ perception in this region. Perception studies of this sort provide an understanding of farmer familiarity with key $\mathrm{SH}$ concepts, which is a first step for farmer engagement in improving $\mathrm{SH}$ on their farms. Moreover, our results contribute to a more general research agenda that emphasizes the importance of farmer perception in facilitating and improving the design of sustainable farm management strategies in the context of changing biophysical and climate conditions.

\section{Figure 3}

Overall soil health index score of farmers by (a) gender, (b) co-op membership status, and (c) municipalities.

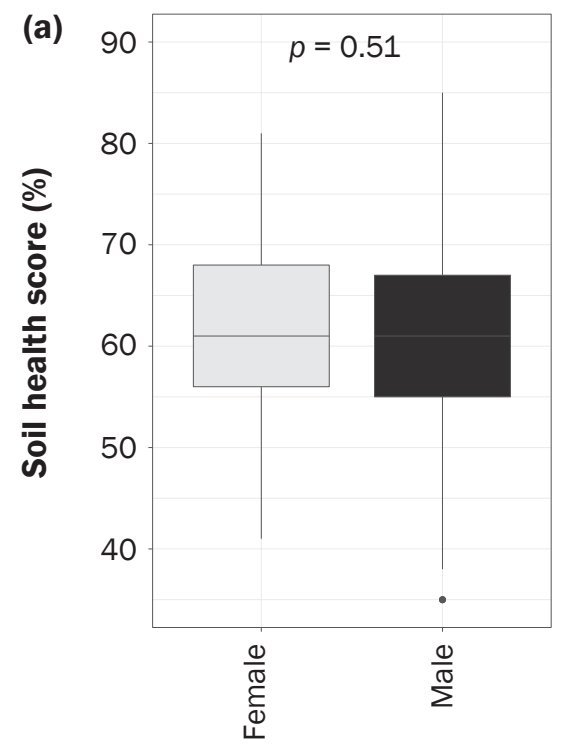

Farmer gender

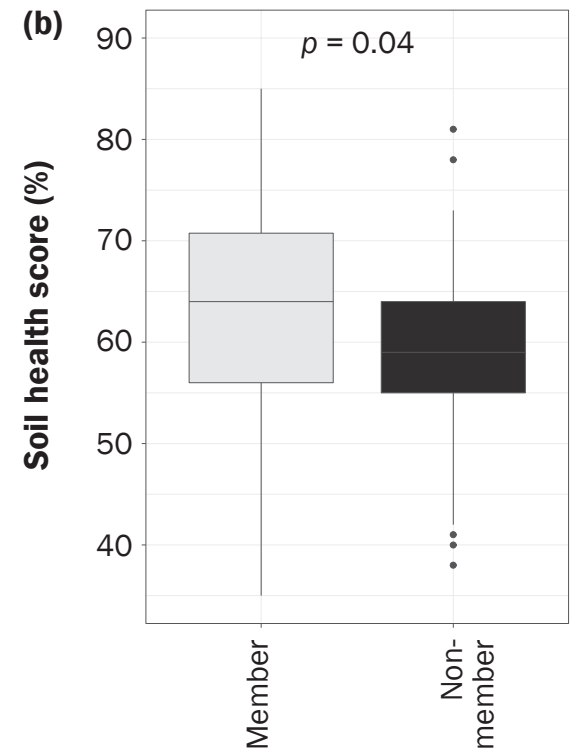

Co-op membership status



Municipalities 
Table 5

Average overall soil health index scores of member farmers by municipality, perceived plot fertility, and gender.

\begin{tabular}{lllllll}
\hline \multirow{2}{*}{ Municipality } & \multicolumn{2}{l}{ Most fertile } & \multicolumn{3}{l}{ Least fertile } & \\
\cline { 2 - 3 } & Male & Female & & Male & Female & Average \\
\hline Rosas & 50.9 & 54.0 & & 47.9 & 43.2 & $49.2 \mathrm{~d} *$ \\
Timbío & 62.8 & 57.5 & & 55.3 & 53.8 & $58.0 \mathrm{bc}$ \\
Piendamó & 61.7 & 70.3 & & 58.1 & 66.7 & $64.3 \mathrm{ab}$ \\
Cajibio & 64.9 & 64.3 & & 65.6 & 55.3 & $62.7 \mathrm{abc}$ \\
Morales & 73.3 & 70.8 & & 66.6 & 71.2 & $70.3 \mathrm{a}$ \\
Popayán & 57.1 & 62.5 & & 50.0 & 55.5 & $55.2 \mathrm{~cd}$ \\
\hline Average & $61.7 \mathrm{a}$ & $63.0 \mathrm{a}$ & $56.9 \mathrm{a}$ & $57.1 \mathrm{a}$ & \\
\hline
\end{tabular}

* Means are significant using Tukey's method at $\alpha=0.05$; $a$, b, and c are significant homogeneous groups.

\section{Table 6}

Soil health indicators that influence farmer soil health perceptions.

\begin{tabular}{lclcc}
\hline Indicator & Estimate & Std. error & $\boldsymbol{z}$ value & $\operatorname{Pr}(>|z|)$ \\
\hline Intercept) & 0.16 & 1.95 & 0.08 & 0.94 \\
OM & 0.26 & 0.08 & 3.25 & $<0.001^{* * *}$ \\
AC & 0.00 & 0.00 & -1.73 & 0.08 \\
AWC & -1.50 & 2.78 & -0.54 & 0.59 \\
Respiration & -2.78 & 1.18 & -2.36 & $0.02 *$ \\
P & -0.03 & 0.05 & -0.50 & 0.62 \\
WAS & -0.03 & 0.03 & -1.06 & 0.29 \\
Protein & 0.44 & 0.11 & 4.11 & $<0.001^{* * *}$
\end{tabular}

Notes: $\mathrm{OM}=$ organic matter. $\mathrm{AC}=$ active carbon. $\mathrm{AWC}=$ available water capacity. $\mathrm{P}=$ phosphorus. WAS $=$ wet aggregate stability.

*significant at $\alpha=0.1 ; * *$ significant at $\alpha=0.05 ; * * *$ significant at $\alpha=0.001$.
Osgood, D., B. Powell, R. Diro, C. Farah, M. Enenkel, M.E. Brown, G. Husak, S. Lucille Blakeley, L. Hoffman, and J.L. McCarty. 2018. Farmer perception, recollection, and remote sensing in weather index insurance: An Ethiopia case study. Remote Sensing 10(12):1887.

R Core Team. 2014. R: A language and environment for statistical computing. Vienna, Austria: R Foundation for Statistical Computing.

Rahman, S. 2005. Environmental impacts of technological change in Bangladesh agriculture: Farmers' perceptions, determinants, and effects on resource allocation decisions. Agricultural Economics 28(4):233-238.

Rekik, F., H. van Es, J.N. Hernandez-Aguilera, and M.I Gómez. 2018. Soil health assessment for coffee farms on andosols in Colombia. Geoderma Regional 14(2018):e00176.

Romig, D.E., M.J. Garlynd, R.F. Harris, and K. McSweeney. 1995. How farmers assess soil health and quality. Journal of Soil and Water Conservation 50(3):229-236.

Ryder, R. 2003. Local soil knowledge and site suitability evaluation in the Dominican Republic. Geoderma 111(3-4):289-305.

Samper, L., and X. Quiñones-Ruiz. 2017. Towards a balanced sustainability vision for the coffee industry. Resources $6(2): 17$.

da Silva Neto,FJ.,K.P.Gomes Morinigo, N.de França Guimarães, A. de Souza Gallo, M.D. Bispo de Souza, R. Stolf, and A. Fontanetti. 2018. Shade trees spatial distribution and its effect on grains and beverage quality of shaded coffee trees. Journal of Food Quality 2018, 7909467

\section{Acknowledgements}

This study is based upon work supported by the National Science Foundation Graduate Research Fellowship Program under Grant No. DGE-1650441 and the Atkinson Center for Sustainable Future. We are grateful for the collaboration of Federación Campesina del Cauca (FCC) and Cooperativa de los Andes, Colombia.

\section{References}

Andrews, S.S., D.L. Karlen, and C.A. Cambardella. 2004. The Soil Management Assessment Framework: A quantitative soil quality evaluation method. Soil Science Society of America Journal 68(6):1945-1962.

de Bruyn, L.A.L., and J.A. Abbey. 2003. Characterisation of farmers' soil sense and the implications for on-farm monitoring of soil health. Australian Journal of Experimental Agriculture 43(3):285-305.

Hernandez-Aguilera, J.N., J.M. Conrad, M.I. Gómez, and A.D. Rodewald. 2019. The economics and ecology of shade-grown coffee: A model to incentivize shade and bird conservation. Ecological Economics 159(2019):110-121.

Hernandez-Aguilera, J.N., M.I. Gómez, A.D. Rodewald, X. Rueda, C. Anunu, R. Bennett, and H.M. van Es. 2018. Quality as a driver of sustainable agricultural value chains: The case of the Relationship Coffee Model. Business Strategy and the Environment 27(2):179-198.

IDEAM. n.d. Promedios Climatológicos 1981-2010.xlsx. Clima. http://www.ideam.gov.co/web/tiempo-y-clima/clima.

Karltun, E., M. Lemenih, and M. Tolera. 2013. Comparing farmers' perception of soil fertility change with soil properties and crop performance in Beseku, Ethiopia. Land Degradation and Development 24(3):228-235.

Knutson, C.L., T. Haigh, M.J. Hayes, M. Widhalm, J. Nothwehr, M. Kleinschmidt, and L. Graf. 2011. Farmer perceptions of sustainable agriculture practices and drought risk reduction in Nebraska, USA. Renewable Agriculture and Food Systems 26(3):255-266.

McDonald, J.H. 2014. Handbook of Biological Statistics, 3rd ed. Baltimore, MD: Sparky House Publishing.

Moebius-Clune, B.N., D.J. Moebius-Clune, B.K. Gugino, O.J. Idowu, R.R. Schindelbeck, A.J. Ristow, H.M. van Es, J.E.Thies, H.A. Shayler, M.B. McBride, K.S.M. Kurtz, D.W. Wolfe, and G.S. Abawi. 2016. Comprehensive Assessment of Soil Health - The Cornell Framework, edition 3.2. Geneva, NY: Cornell University.

Munyuli, T. 2011. Farmers' perceptions of pollinators' importance in coffee production in Uganda.Agricultural Sciences 2(03):318. 